\title{
TRAUMATIC SHOCK. XIV. THE SUCCESSFUL TREATMENT OF HEMORRHAGIC SHOCK BY VIVI-PERFUSION OF THE LIVER IN DOGS IRREVERSIBLE TO TRANSFUSION ${ }^{1}$
}

\author{
By ARNOLD M. SELIGMAN, HOWARD A. FRANK AND JACOB FINE \\ (From the Surgical Research Department, Beth Israel Hospital, Boston, and the Department \\ of Surgery, Harvard Medical School, Boston)
}

(Received for publication January 1, 1947)

The development of irreversibility to transfusion in the dog in hemorrhagic shock can be prevented by vivi-perfusion of the liver with arterial blood from a donor animal (1). The peculiar relationship of the liver to hemorrhagic shock is emphasized by the fact that vivi-perfusion via other channels does not prevent the development of irreversibility to transfusion. If the loss of integrity of the liver parenchyma is the key to the problem of peripheral circulatory collapse in shock, it becomes important to determine to what extent the damage to liver cells, if allowed to occur, may be corrected by restoring normal oxygen and volume flow requirements to the damaged liver cells. This problem was attacked by allowing the dog to develop irreversibility to transfusion and then perfusing the liver by cross-circulation with a donor dog. Repair of liver cell injury should then be reflected in a reversal of the rapidly progressive deterioration of the peripheral circulation characteristic of advanced shock. This communication will present data showing that hemorrhagic shock which has not responded to transfusion can be successfully treated by cross-circulation of the liver via the splenic vein with a healthy donor dog and that cross-circulation via a systemic vein is not effective.

\section{METHOD}

Hemorrhagic shock was induced in non-anesthetized dogs who had been given a single intramuscular injection of morphine $(2 \mathrm{mgm}$. per $\mathrm{kgm}$.). Incisions were made under local anesthesia. Those dogs which were to be perfused via the splenic vein were prepared 1 to 3 weeks in advance by splenectomy and subcutaneous implantation of a large splenic vein. In a few instances this vein was found to be occluded. Such dogs together with other normal dogs were used for perfusion via a systemic vein.

1 The work described in this paper was done under a contract, recommended by the Committee on Medical Research, between the Office of Scientific Research and Development and Harvard University.
Shock was induced by bleeding from a femoral artery attached to an elevated reservoir so that the blood pressure was maintained at $30 \mathrm{~mm}$. $\mathrm{Hg}$ until "irreversibility" was considered to have developed in accordance with standards previously described (1). All shed blood was then rapidly infused via a femoral vein and the post-transfusion course was observed until it was clear that the animal had again relapsed into shock. At this time cross-circulation with a normal donor dog of about the same size was started (Figure 1). Blood from the donor dog's femoral artery, which was connected by means of clean (alkali-treated), but not sterile, rubber and glass tubing to the splenic or femoral vein of the dog in shock, was returned to the donor's femoral vein from the femoral artery of the dog in shock. Flowmeters were interposed in the delivery and return circuits. These were constructed as previously described (1) except that the dimensions of the return flowmeter were altered to accommodate the flow from the recipient at a higher pressure than obtained in the previous series (1). Continuing failure of the shocked dog's circulation was manifest by progressive decline in the recipient's blood pressure and evidence of exsanguination of the donor into the recipient. Both animals were maintained above shock levels of blood pressure by adding heparinized blood taken from other normal dogs. Crosscirculation was continued until the recipient dog was obviously terminal or had recovered sufficiently to maintain a normal blood pressure without added blood. Crosscirculation was then terminated. All vessels were ligated, sulfanilamide powder was placed in the wounds, and the incisions were closed.

Lactic acid, glucose, amino acid nitrogen, and non-protein nitrogen were measured in specimens of arterial blood by the methods previously used (1). Blood urea nitrogen was determined by the method of Karr (2).

\section{RESULTS}

Data on 9 liver-perfused and 9 control dogs are given in Tables I and II. No evidence of a toxic substance passing from the dog in irreversible shock to the donor was noted. Drops in donor blood pressure were considered as evidence of "taking-up" 2 by the recipient dog. When the vol-

2 If the dog in hemorrhagic shock bleeds into an elevated reservoir, connected to a large artery, until the falling 


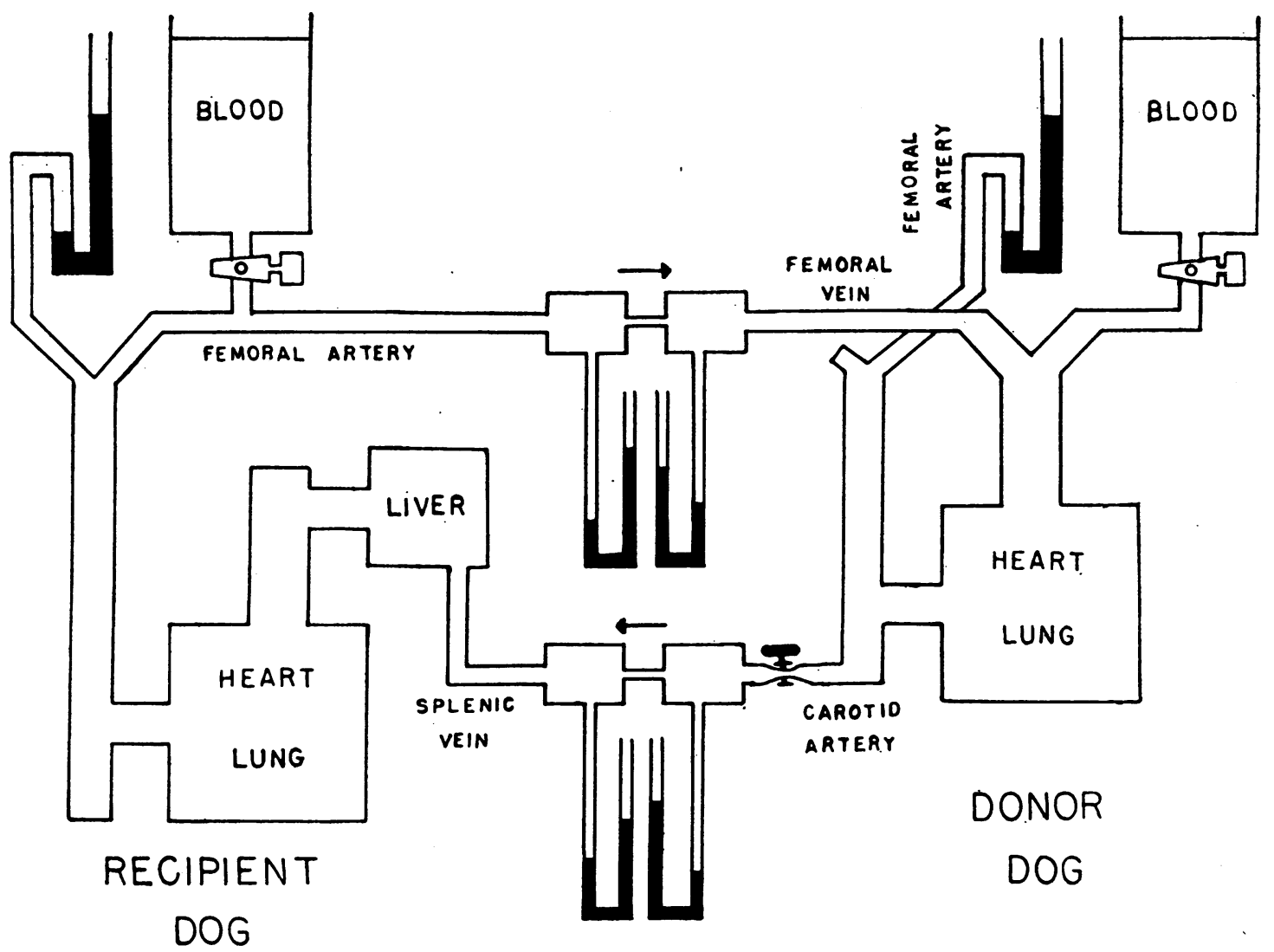

Fig. 1. Diagrammatic Representation of the Vascular Circuit in Liver Perfusion

ume of blood lost to the recipient during the "taking-up" period was replaced and the donor's blood pressure returned to normal, the donor remained in good condition for the rest of the experiment. Several experiments in which technical accidents resulted in death of the donor dog were discarded.

blood pressure equals the hydrostatic pressure $(30 \mathrm{mgm}$. $\mathrm{Hg}$ ) in the reservoir, the dog remains stabilized at this pressure until after some time, varying from $11 / 2$ to 3 hours, when blood begins to return from the reservoir to the artery. The sustaining effect of this additional blood on the blood pressure is slight and short-lived and the "taking-up" of blood by the dog from the reservoir proceeds continuously or intermittently but with increasing speed until death. If one substitutes for the reservoir a donor dog in circuit with the dog in shock before the "taking-up" process begins or while it is in progress, the donor dog will serve as a reservoir and his blood pressure will fall as he exsanguinates himself into the recipient. The added blood pools in the recipient's peripheral vascular bed, which, having lost tone, dilates passively to receive the blood. This "taking-up" phenomenon, previously described in Paper XIII of the series (1), is an objective method of visualizing the progressive collapse of the peripheral circulation in the dog in shock.
The control dogs (Table I) showed little or no benefit from the cross-circulation. "Taking-up," which is an objective demonstration of paralysis of peripheral vascular tone and trapping of blood (3), not only continued after cross-circulation was started but often increased in the next hour or two so that it became difficult to sustain the blood pressure of the recipient (Table III). The blood pressure continued to fall in spite of the infusion of 1 to 2 or 3 times the estimated total blood volume in addition to the original transfusion. Crosscirculation was discontinued when the blood pressure declined to $30 \mathrm{~mm}$. $\mathrm{Hg}$ and the dog was virtually in terminal shock. The period of cross-circulation was shorter in the control series than in the liver-perfused group because of the rapid decline and early death. Seven of the 9 dogs died within 12 hours after starting cross-circulation. Some of these dogs had severe bloody diarrhea. One dog died in 18 hours and one dog (LT 26) survived 1 day. The latter dog might have lived this long without cross-circulation, because the post-trans- 
fusion period of decline in blood pressure to the level selected for beginning cross-circulation was exceptionally long ( $3 \frac{3}{4}$ hours).

The liver-perfused dogs (Table II) exhibited several interesting phenomena. "Taking-up," which was as active as in the controls for the first hour or two of cross-circulation, gradually slowed up or disappeared (Table III), an index, we believe, of the recovery of tone in the peripheral vascular system. The blood pressure, which at first was difficult to maintain above 70 to $80 \mathrm{~mm}$. $\mathrm{Hg}$, climbed steadily and eventually stabilized at or above $100 \mathrm{~mm}$. $\mathrm{Hg}$. After some 5 hours of cross-circulation, marked clinical improvement was evident from the return of alertness, restlessness, quick response to environmental stimuli, and the excretion of urine. At this stage cross-circulation was discontinued. After the wounds were

TABLE I

The effect of vivi-perfusion via the femoral vein (controls)

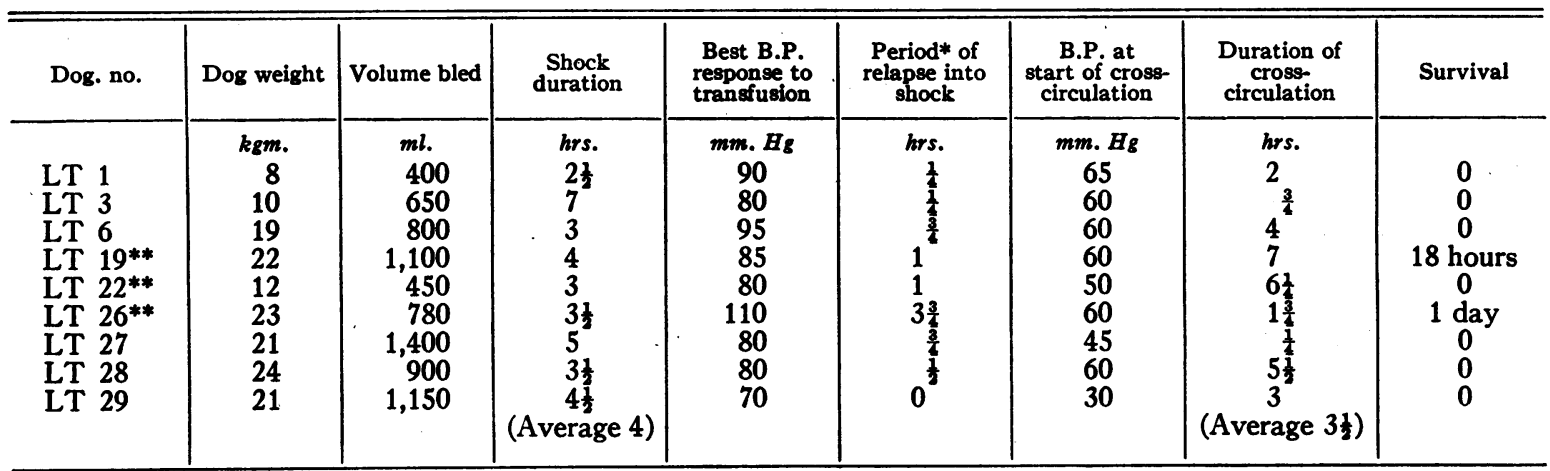

* Period between end of transfusion and start of cross-circulation.

** Splenectomy done 1 to 3 weeks earlier.

TABLE II

The effect of vivi-perfusion via the splenic vein (liver-perfused dogs)

\begin{tabular}{|c|c|c|c|c|c|c|c|c|c|}
\hline $\begin{array}{l}\text { Dog } \\
\text { no. }\end{array}$ & $\begin{array}{c}\text { Dog } \\
\text { weight }\end{array}$ & $\begin{array}{l}\text { Volume } \\
\text { bled }\end{array}$ & $\begin{array}{c}\text { Shock } \\
\text { duration }\end{array}$ & $\begin{array}{l}\text { Best B.P. } \\
\text { response } \\
\text { to trans- } \\
\text { fusion }\end{array}$ & $\begin{array}{l}\text { Period* } \\
\text { of relapse } \\
\text { into } \\
\text { shock }\end{array}$ & $\begin{array}{c}\text { B.P. at } \\
\text { start of } \\
\text { cross- } \\
\text { circulation }\end{array}$ & $\begin{array}{l}\text { Duration } \\
\text { of cross- } \\
\text { circulation }\end{array}$ & Survival & Remarks \\
\hline LT 4 & $\begin{array}{c}\mathrm{kgm} . \\
18\end{array}$ & $\begin{array}{l}m l . \\
750\end{array}$ & $\begin{array}{l}\text { hrs. } \\
3\end{array}$ & $\begin{array}{c}m m . H g \\
60\end{array}$ & hrs. & $\underset{75}{m m .} \mathrm{Hg}_{\mathrm{g}}$ & $\begin{array}{l}\text { hrs. } \\
6\end{array}$ & $\begin{array}{r}\text { days } \\
+(1)\end{array}$ & $\begin{array}{l}\text { Decorticate after } \\
\text { drop in B.P. fol- } \\
\text { lowing ligation of } \\
\text { splenic pedicle at } \\
\text { end of experiment }\end{array}$ \\
\hline $\begin{array}{l}\text { LT } 7 \\
\text { LT } 8\end{array}$ & $\begin{array}{l}16 \\
20\end{array}$ & $\begin{array}{l}525 \\
400\end{array}$ & $\begin{array}{l}2 \frac{1}{2} \\
4\end{array}$ & $\begin{array}{r}80 \\
100\end{array}$ & $\begin{array}{l}1 \\
3 \frac{1}{4}\end{array}$ & $\begin{array}{l}50 \\
65\end{array}$ & $\begin{array}{l}1 \\
4 \frac{1}{6}\end{array}$ & $\begin{array}{l}0 \\
+(7+)\end{array}$ & Sacrificed in good \\
\hline LT 18 & 19 & 550 & 2 & 70 & 0 & 60 & $8 \frac{3}{4}$ & $+(7+)$ & Sacrificed in good \\
\hline $\begin{array}{ll}\text { LT } & 20 \\
\text { LT } & 21\end{array}$ & $\begin{array}{l}20 \\
21\end{array}$ & $\begin{array}{l}700 \\
800\end{array}$ & $5 \frac{1}{2}$ & $\begin{array}{r}80 \\
110\end{array}$ & $1^{\frac{1}{2}}$ & $\begin{array}{l}50 \\
60\end{array}$ & $\begin{array}{l}6 \\
5 \frac{1}{2}\end{array}$ & $\begin{array}{l}+(3) \\
+(7+)\end{array}$ & $\begin{array}{l}\text { Sacrificed in good } \\
\text { health }\end{array}$ \\
\hline $\begin{array}{ll}\text { LT } 23 \\
\text { LT } 24\end{array}$ & $\begin{array}{l}24 \\
19\end{array}$ & $\begin{array}{l}1,000 \\
1,000\end{array}$ & $3 \frac{1}{4}$ & $\begin{array}{l}100 \\
100\end{array}$ & $1^{\frac{1}{2}}$ & $\begin{array}{l}50 \\
40\end{array}$ & $\begin{array}{l}6 \\
5 \frac{1}{2}\end{array}$ & $\begin{array}{l}+(2) \\
+(2)\end{array}$ & $\begin{array}{l}\text { Severe pulmonary } \\
\text { congestion at } \\
\text { autopsy }\end{array}$ \\
\hline LT 25 & 21 & 1,100 & $\begin{array}{c}7 \frac{3}{4} \\
\text { (Average 4) }\end{array}$ & 70 & $\frac{1}{2}$ & 50 & (Average 5 & $+(2)$ & $\begin{array}{l}\text { cerebral damage } \\
\text { during periods of } \\
\text { accidental blood } \\
\text { loss during experi- } \\
\text { ment }\end{array}$ \\
\hline
\end{tabular}

* Period between end of transfusion and start of cross-circulation. 
TABLE III

"Taking-up" during vivi-perfusion

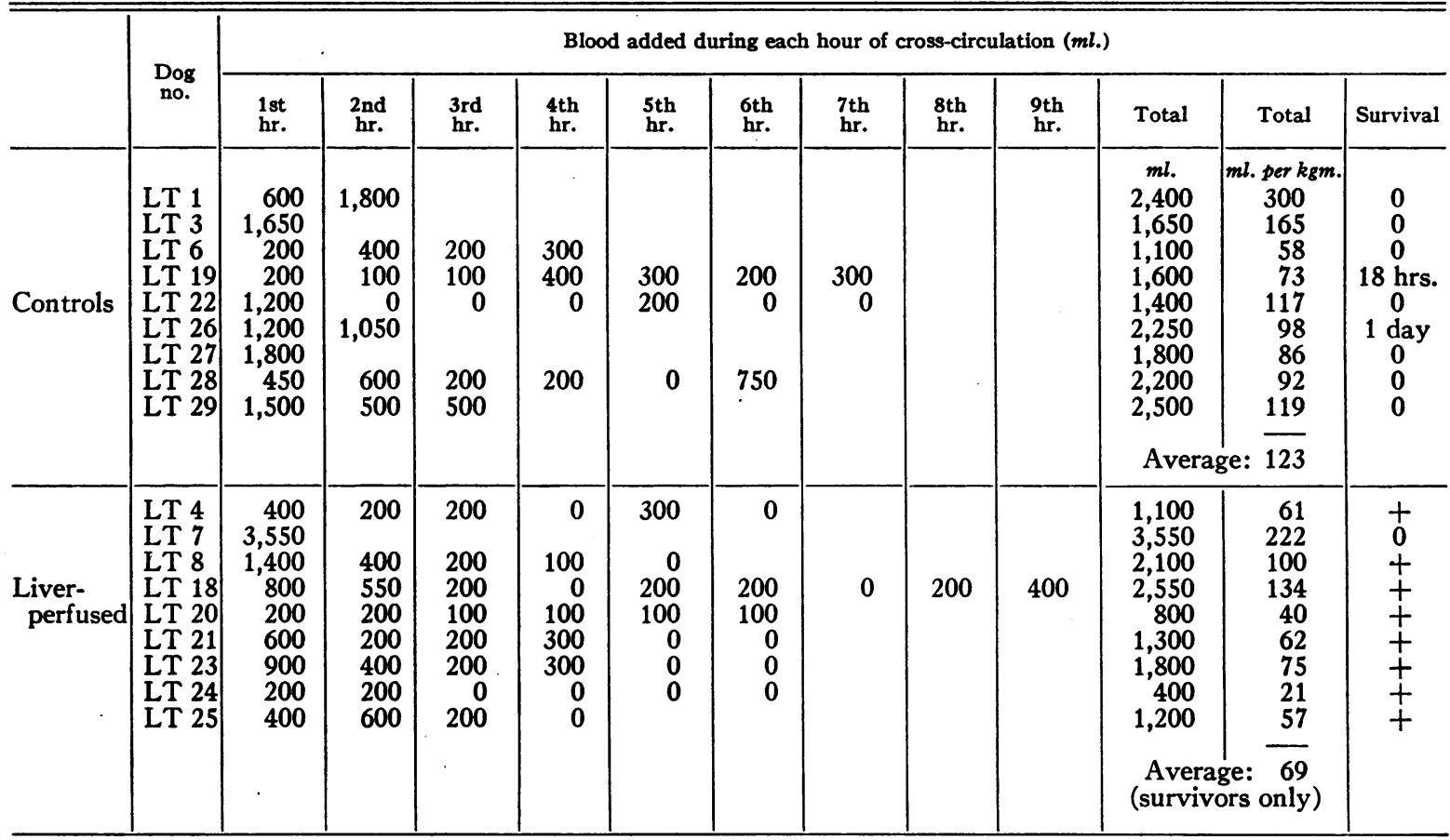

repaired, the dogs were removed from the operation table, appeared strong, walked, and drank water.

Of 9 dogs, 8 survived 1 or more days, which is considered survival from the point of view of the shock state. Dog 7, which died 1 hour after beginning cross-circulation, showed such rapid and unabated "taking-up" as to indicate the onset of terminal shock before liver repair could be achieved. No precautions against infection were observed during the experiments and no after-care was provided for the surviving animals. Bloody diarrhea was observed in 3 dogs. The blood NPN level was normal several days after the experiment in the 2 dogs in which this determination was made. One dog, which died. after 48 hours, showed bilateral pneumonia. Three were sacrificed after 7 days. Another, which developed a temporary severe hypotension when the splenic pedicle was tied upon discontinuing the perfusion, became decorticate and, though not in shock, died some 28 hours later. In unanesthetized dogs, gross evidence of brain damage does not appear during the interval of these experiments at blood pressure levels of $30 \mathrm{~mm}$. $\mathrm{Hg}$ or higher. But even momen- tary drops below this pressure result in respiratory failure and signs of decortication. Such drops occasionally occurred in these experiments. Their immediate correction restored normal respiration, but if signs of decortication persisted, the survival period after recovery from shock did not last more than 1 to 2 days.

Data are given in Table IV showing the effects of cross-circulation on the blood concentration values of 4 metabolites. It will be observed that the blood lactic acid, which has already been reduced by the original transfusion (4), is still further reduced by cross-circulation. But since the magnitude of the reduction is equally great in both series, it may be concluded that the lactic acid level bears no relation to the outcome of the shock state. A similar conclusion was reached from other data (4). The fall in blood glucose that occurs after the original transfusion is not alleviated by crosscirculation. The sustained glucose level of the donor in the liver-perfused series indicates that the demand on the donor animal for glucose from the liver-perfused recipient is not so great as from the control recipient. The amino-acid level in the liver-perfused series is somewhat reduced by cross- 
TABLE IV

Analyses of blood from the shocked dog before and during vivi-perfusion, in liver-perfused dogs and in controls

Each figure is an average of all experiments. The number of determinations represented in the average is given in the right upper corner of each box. The figure in parenthesis is the average value for the analyses of samples of the donors' blood, taken at the same time as the repients'.

\begin{tabular}{|c|c|c|c|c|c|c|}
\hline & & \multirow{2}{*}{$\begin{array}{l}\text { Nor- } \\
\text { mal }\end{array}$} & \multicolumn{2}{|c|}{ Shock } & \multicolumn{2}{|c|}{ Cross-circulation } \\
\hline & & & $\begin{array}{l}\text { Before } \\
\text { trans- } \\
\text { fusion }\end{array}$ & $\begin{array}{l}\text { After } \\
\text { trans- } \\
\text { fusion }\end{array}$ & $0-4$ hrs. & 4-8 hrs. \\
\hline \multirow{2}{*}{$\begin{array}{l}\text { Lactic Acid } \\
\text { (mgm } \\
\text { per cent) }\end{array}$} & $\int \begin{array}{c}\text { liver- } \\
\text { perfused } \\
\text { dogs }\end{array}$ & $\begin{array}{r}9 \\
28.5\end{array}$ & $\begin{array}{r}5 \\
89.0^{5}\end{array}$ & $\begin{array}{r}5 \\
71.5\end{array}$ & $\begin{array}{ll} & 5 \\
37.0 & \\
& \\
& \end{array}$ & $29.0_{(43.0)}^{4}$ \\
\hline & controls & $28.5^{9}$ & $85.5^{3}$ & $54.5^{5}$ & $\begin{array}{lr}40.5 & 5 \\
& (38.5)\end{array}$ & $\overline{30.0 \quad 2}$ \\
\hline \multirow{2}{*}{$\begin{array}{l}\text { Glucose } \\
\text { (mgm. } \\
\text { per cent) }\end{array}$} & $\int \begin{array}{c}\text { liver- } \\
\text { perfused } \\
\text { dogs }\end{array}$ & 109 & 102 & 87 & $\begin{array}{ll}86 & \\
& (95)\end{array}$ & \begin{tabular}{|rr} 
& 4 \\
& \\
70 & \\
& $(141)$
\end{tabular} \\
\hline & controls & $109^{8}$ & $135^{3}$ & $88 \cdot 3$ & 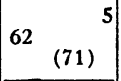 & 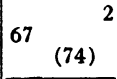 \\
\hline \multirow{2}{*}{$\underset{\substack{\text { pergm. } \\
\text { pent })}}{\text { Amino N }}$} & $\left\{\begin{array}{c}\text { liver- } \\
\text { perfused } \\
\text { dogs }\end{array}\right.$ & $\begin{array}{r}14 \\
11.4\end{array}$ & $20.7^{7}$ & $19.2^{5}$ & 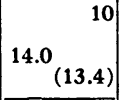 & \begin{tabular}{|r} 
\\
\\
14.5 \\
$(16.0)$ \\
\end{tabular} \\
\hline & controls & $11.4^{14}$ & $16.2^{5}$ & $14.6^{4}$ & \begin{tabular}{|lr}
14.4 & 9 \\
& $(11.8)$
\end{tabular} & \begin{tabular}{|r}
18.4 \\
\\
\end{tabular} \\
\hline \multirow{2}{*}{$\begin{array}{l}\text { Urea } \mathrm{N} \\
\text { (mgm. } \\
\text { per cent) }\end{array}$} & $\left\{\begin{array}{c}\text { liver- } \\
\text { perfused } \\
\text { dogs }\end{array}\right.$ & $\begin{array}{r}12 \\
8.9\end{array}$ & $22.2^{5}$ & $20.9^{4}$ & 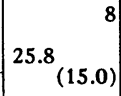 & $\begin{array}{rr}5 \\
25.2 \\
\\
\end{array}$ \\
\hline & controls & $8.9^{12}$ & $20.7^{5}$ & $15.2^{4}$ & \begin{tabular}{|rr}
17.6 & 9 \\
& \\
& $(16.2)$
\end{tabular} & $\begin{array}{rr}20.6 \quad 3 \\
(20.2)\end{array}$ \\
\hline
\end{tabular}

circulation, but is uninfluenced in the control series. Urea synthesis proceeds during the shock state and the donor is unable to reduce the bloodurea level. The shifts in the levels of these metabolites affect donor and recipient about equally, with the exception of glucose in the liver-perfused series. There is no evidence from these data that alterations in the blood levels of these metabolites bear any relation to survival or death of the dog in hemorrhagic shock.

\section{DISCUSSION}

These experiments demonstrate that vivi-perfusion of the liver for 5 to 9 hours with arterial blood from a donor animal is an effective therapeutic agent for the treatment of hemorrhagic shock which fails to respond to restoration of normal blood volume and to other agents (5). The con- tribution of the donor animal consists at least in furnishing a sufficient volume flow of arterial blood to the liver. Does the donor animal contribute something more, such as supplies of glucose and other metabolites, electrolytes, enzymes, and detoxifying or equilibrating processes not available to the dog in shock, e.g. renal function? Since such additional benefits are also available to the control dog, the specific and crucial service furnished by the donor must be related to what is supplied directly to the recipient's liver. It is the response of the recipient's liver to this service which results after several hours of cross-circulation in the slowing up and disappearance of the "takingup" phenomenon and the concurrent recovery of peripheral vascular tone, which is evident from the progressive improvement in the hemodynamics and the disappearance of the shock state.

Our data in a previous publication do not contradict or support the inference that a toxic factor, such as the vaso-depressor material of Shorr et al (6), can be implicated as the chief factor in the collapse of the peripheral vascular mechanism. The data herewith presented likewise do not allow of such an inference. It should be added, however, that, if such an inference is not permissible, it is equally invalid on the same evidence to conclude that a protective factor, such as a normally secreted humoral product of hepatic origin, may be invoked to account for.the stability or recovery of the peripheral circulation-else why should the donor with a healthy liver fail to support the failing circulation of the control animal?

Whether those functions provided by the donor, which are also available to the control recipient, are or are not indispensable accessories to those supplied by liver perfusion remains to be determined.

What is quite clear from the data at hand is that "irreversibility" in hemorrhagic shock under the experimental conditions described is a result of hepatic injury and that the solution of the problem must be directed toward prevention or correction of hepatic injury. ${ }^{3}$

\footnotetext{
"The interesting facts stand out that a trifling injury (to the liver) due to phosphorus or chloroform can

3 The relationship between hepatic injury and shock was observed by Whipple and his coworkers (7) who wrote the following:
} 
be tolerated by a dog with no clinical reaction. But if at this time ... we perform a plasmapharesis of small volume which was previously tolerated by the same dog with little to no intoxication, we immediately precipitate severe or fatal shock. ... The chloroform or phosphorus causes an injury to many liver cells and these cells are more susceptible to other injurious agents than are normal liver cells. A sudden change in the protein content of the blood which bathes these injured cells will react more unfavorably upon them than upon the healthy and more resistant normal liver cells. These damaged (phosphorus) and then shocked (plasmapharesis) liver cells form substances which are taken up by the blood and carried to all living cells of the body. If these poisonous substances are suffcient in amount, we observe the development of lethal shock. ...

"We observe in other experiments that cell injury of other organs (kidney, pancreas, and intestine) does not modify the familiar reaction following a moderate exchange. The control and poisoning experiments give similar reactions. This indicates a peculiar relation of the liver cells to the shock reaction associated with plasma depletion."

\section{SUMMARY AND CONCLUSIONS}

Eight of the 9 dogs in hemorrhagic shock irreversible to transfusion recovered after perfusion of the liver by cross-circulation via the splenic vein with a healthy donor dog. Seven of 9 dogs similarly treated, except that the donor's blood entered the femoral instead of the splenic vein, did not survive.

These observations demonstrate (1) that liver damage is intimately related to the collapse of the peripheral vascular mechanism in advanced hemorrhagic shock, (2) that restoration of the integrity of the liver is necessary for recovery of function of the peripheral vascular system in advanced hemorrhagic shock, and (3) that restoration of this aspect of liver function can be accomplished byproviding adequate blood flow from a donor dog to the liver, even after "irreversibility" to transfusion has been demonstrated.

Acknowledgment of technical assistance is made to $\mathrm{Mr}$. Thomas W. Barnett, Miss Gertrude Weinberger, Mrs. R. B. Griffin, and Miss Dorothy Kaufman.

\section{BIBLIOGRAPHY}

1. Frank, Howard A., Seligman, Arnold M., and Fine, Jacob, Traumatic shock. XIII. The prevention of irreversibility in hemorrhagic shock by vivi-perfusion of the liver. J. Clin. Invest., 1946, 25, 22.

2. Karr, W. G., A method for the determination of blood urea nitrogen. J. Lab. and Clin. Med., 1924, 9, 329.

3. Gibson, J. G., 2nd, Seligman, Arnold M., Peacock, Wendell C., Fine, Jacob, Aub, Joseph C., and Evans, Robley D., The circulating red cell and plasma volume and the distribution of blood in large and minute vessels in experimental shock in dogs measured by radioactive isotopes of iron and iodine. J. Clin. Invest., 1947, 26, 126.

4. Seligman, Arnold M., Frank, Howard A., Alexander, Benjamin, and Fine, Jacob, Traumatic shock. XV. Carbohydrate metabolism in hemorrhagic shock in the dog. J. Clin. Invest., 1947, 26, 536.

5. Frank, Howard A., Seligman, Arnold M., and Fine, Jacob, Traumatic shock. $\mathrm{X}$. The treatment of hemorrhagic shock irreversible to replacement of blood volume deficiency. J. Clin. Invest., 1945, 24, 435.

6. Shorr, Ephraim, Zweifach, Benjamin W., and Furchgott, Robert F., On the occurrence, sites, and modes of origin and destruction of principles affecting the compensatory vascular mechanisms in experimental shock. Science, 1945, 102, 489.

7. Whipple, G. H., Smith, H. P., and Belt, A. E., II. Shock as a manifestation of tissue injury following rapid plasma protein depletion. Am. J. Physiol., 1920, 52, 72. 